\title{
The violent frontline: space, ethnicity and confronting the state in Edwardian Spitalfields and 1980s Brixton
}

Article

Accepted Version

Renshaw, D. (2018) The violent frontline: space, ethnicity and confronting the state in Edwardian Spitalfields and 1980s Brixton. Contemporary British History, 32 (2). pp. 231-252. ISSN 1743-7997 doi:

https://doi.org/10.1080/13619462.2018.1434001 Available at https://centaur.reading.ac.uk/75036/

It is advisable to refer to the publisher's version if you intend to cite from the work. See Guidance on citing.

To link to this article DOI: http://dx.doi.org/10.1080/13619462.2018.1434001

Publisher: Routledge

All outputs in CentAUR are protected by Intellectual Property Rights law, including copyright law. Copyright and IPR is retained by the creators or other copyright holders. Terms and conditions for use of this material are defined in the End User Agreement.

www.reading.ac.uk/centaur 
Central Archive at the University of Reading

Reading's research outputs online 


\title{
The violent frontline: Space, ethnicity and confronting the state in Edwardian Spitalfields and 1980s Brixton
}

\author{
FCBH-2017-0016
}

'To put the subject in some sort of historical context, violence of one sort or another is the norm... Modern policing can only work with the cooperation and consent of the community and when, for one reason or another, this breaks down, there is a risk of riot or, in extreme cases, revolution. While the precipitants involve minority groups in conflict with authority, and may turn on some symbolic act which transgresses social values, interests or norms, the underlying causes are undoubtedly complex, involving as they do a plethora of independent variables.' Internal Home Office Report, 13 July $1981^{1}$

In the modern period, Britain has experienced a number of episodes of serious physical confrontation between state and citizens. The 'rioter', stereotypically young, from a deprived socio-economic background, face concealed and facing a line of shielded police officers wielding batons, is a contemporary and very effective folk devil. ${ }^{2}$ Serious communal violence is invariably depicted contemporaneously in the popular press as causeless ('mindless hooliganism') or avaricious (looting), with the participants being 'malcontents, meddlesome, troublemakers...' ${ }^{3}$ Nevertheless, over the last fifty years, sociologists, human geographers and historians have attempted to map the causes, patterns and aims of collective violence, the ebb and flow of the riot, and in particular the utility of violence in negotiating distribution of resources between the state and the disenfranchised. This field of study gained a substantial impetus from the urban unrest during the American 'long hot summers' of the 1960s. ${ }^{4}$ 
This article will compare two instances of severe communal anti-state violence in twentieth century London, using the context and course of the Spitalfields bakers' strike of 1906 and the anti-police violence in Brixton in 1981 to examine the relationship between diasporic identity, space and physical force in the modern metropolis. The first confrontation grew out of militant Jewish trade unionism and inter-communal class conflict, the second a result of resentment at endemic police harassment of primarily Caribbean youth, but both provide insights into the negotiations of belonging and identity inherent in politicised violence within 'diaspora space'. ${ }^{5}$ It will examine the processes behind these confrontations using as key archival texts the social investigation of the 1890s and 1900s, and sociological work on Caribbean communities carried out between 1960 and 1988. In the latter case this will range from early work on recently-arrived migrants undertaken by social scientists from outside the community such as Shelia Patterson, through the work of the Institute of Race Relations, Robert Moore and Stuart Hall in the 1970s, up to analyses, sympathetic or otherwise, responding to the 1981 and 1985 disturbances.

This examination will combine comparative historical methodology with the sociology-based precepts of human and social geography to dissect concepts of violence and identity in the Edwardian and Thatcherite periods. ${ }^{6}$ In London, as in other urban areas, certain locations have at certain chronological points become associated with demographic change generally and the experiences of certain diasporic groups in particular, where, ' $\ldots$ different areas of cities... have literally and metaphorically been developed and "invented" through their racialized interpretation. ${ }^{77}$ These areas constitute 'othered' space, where a geographical area becomes simultaneously associated with a minority group or groups, and serves as a geographical shorthand for the wider societal experiences of migrant communities and reactions to minorities. This space can also be demarcated conceptually from the wider 'host' society and its values, serving as an inversion or rejection of these values. 
This article, focusing on 'Jewish' Spitalfields and 'Caribbean' Brixton, will address three points - how these spatial associations with long-term demographic changes in British society were framed in anti-migrant discourse, how police and people interacted within that space on a political and emotional level, and finally how these interactions resulted in communal violence between police and population in the areas in 1906 and 1981. Both Spitalfields and Brixton were 'boundary' areas where various societal tensions coalesced and eventually expressed themselves in extreme violence at the 'frontline', and also areas of 'diaspora space' in which minorities and the host society interacted in a number of different ways. ${ }^{8}$ Although the Brixton disturbances led to a far-wider subsequent public debate on the relationship between ethnicity, policing, violence and disenfranchisement, both 1906 and 1981 constitute key dramatic signifiers of the changing perceptions and self-perceptions of a marginalised migrant community. Both Edwardian East London and post-war South London formed sites of social investigation in the periods under consideration.

This article takes its methodological grounding from three examinations employing a comparative approach to highlight key issues of ethnicity and the relationship with the state in diasporic London: Anne Kershen's multi-generational comparisons of Huguenot, Jewish and Bangladeshi communities in Spitalfields, Jennifer Davis's ground-breaking work comparing Irish slums in mid-nineteenth century London and the Broadwater Farm estate in Tottenham in the 1980s, and Sarah Glynn's comparative analysis on Jewish and Bengali radicalism in the context of housing provision in the East End. ${ }^{9}$ In doing so we must recognise the warnings of Michael Rowe and Peter Jackson against attempting to formulate over-arching theories of racism or prejudice and the inherent dangers of historians or sociologists creating 'one size fits all' definitions of something as inherently irrational as ethnic hatred and tension. ${ }^{10}$ Antisemitic and anti-Caribbean racisms in Great Britain have different histories, different contexts, different manifestations, and different dynamics at 
work, just as anti-Irish, anti-South Asian or anti-Romany racisms do. Nevertheless, it is also important to recognise confluences that emerge in the Jewish and Caribbean experience on the 'frontline', and that the difficult and sometimes violent relationship between the British police and minority groups did not begin in the 1950s, but can be traced back to previous 'white' diasporic groups settled in urban Britain from the nineteenth century. ${ }^{11}$

The unrest that took place across Britain between 1980 and 1985 proved to be the catalyst for a significant expansion of discussion on the relationship between space, ethnicity and the exercise of state hegemony, pioneered by sociologists writing for the Race and Class journal and associated organisations. This initially focused principally on second and third generation Caribbean youth in inner-city areas. As the historiography evolved this focus began to shift to other marginalised groups, with a number of studies addressing the relationship between South Asian diasporas and space, examining both the Bengali communities in the East End and British-Asian youth in the northern mill towns, with an emphasis in the latter case on communal spatial polarisation. ${ }^{12}$ In Jon May's 'Globalisation and the Politics of Place' (1996) the dialogue expands to take in three groups intersecting and contesting 'diaspora space' on a physical and emotional level; an indigenous working class, migrants and their descendants, and middle class interlopers acting as the agents of gentrification. May's article demonstrates the ways in which contested space can marginalise communities as the socioeconomic nature of that space is altered. ${ }^{13}$ In a similar vein Paul Watt has more recently examined the relationship between space, nostalgia and prejudice on London council estates, and the way in which the space of the neighbourhood (in this case housing estates in Camden) is viewed by its inhabitants. ${ }^{14}$ The interplay between space and various forms of belonging in diasporic London has most recently been dissected by Stephen Brooke, who has adopted a dual perspective on space and emotion by examining demarcation of council estate space in the East End in the 1970s and 1980s as 'white' or 'Asian', a demarcation maintained 
by intimidation and racial violence against Bangladeshi EastEnders. ${ }^{15}$ Brooke thus combines the tangible (the demographic make-up of a council estate), with the intangible (how protagonists feel about this demarcation and how responses are emotionally predicated).

This present study is intended to build upon and expand this discussion by comparing two diasporic subaltern groups which share neither a chronological nor spatial commonality, but which did share a complex physical and emotional relationship with metropolitan space on a hegemonic frontline that was contested by the instruments of state control. The detailed context of the two case studies examined will be used to demonstrate how belonging and violence operate in diasporic areas, as well as how the internal narratives of migrant groups and those of migrant heritage evolve, and the durability of 'colonial' definitions of space and the inhabitants of the 'front-line'. These concepts of physical and emotional contestation cannot be 'boxed in', categorised in a neatly demarcated and isolated migrant experience, shorn of the wider context of a two hundred year history of cooperation and conflict between diasporic outsider groups and the state, but should be expanded to become multi-diasporic, multi-generational and multi-spatial in scope.

Othered space and discourse in Spitalfields and Brixton

Spitalfields had become fixed in the popular consciousness with the Ripper Murders of 1888, and the area more generally with violence and criminality for a considerable period of time before that, an association that survived into the twentieth century. ${ }^{16}$ In physical terms Spitalfields contained some of the worst and most inadequate housing in the capital, with multi-tenancy occupancy of sub-let barely fit property and proportionately extortionate rents. Infrastructure and criminality were bound together, the lay-out of the back-to-back tenements aiding those attempting an escape from the police. ${ }^{17}$ Spitalfields was also a key area of Jewish settlement in the capital, and as with Brixton two generations later, migration, ethnic outsider 
status and criminality were conflated and combined in societal/police perceptions. ${ }^{18}$ Spitalfields was at the heart of a changing metropolitan demography and a retrospective rewriting of social history; the 'old' pre-Jewish English and Irish East End was depicted in contemporary anti-migrant literature in idealised terms (ignoring existing severe ethnic tensions surrounding mid-nineteenth century Irish immigration), whilst the 'new' East End, shaped by the settlement of tens of thousands of refugees from Eastern Europe, was referred to in anti-migrant polemic as 'Jerusalem-on-Thames' or simply as 'Jewtown', both a spatial and a psychological 'other', an expanding alien territory in the heart of the capital. ${ }^{19}$ In Life and Labour of the People in London, Charles Booth wrote:

Jewish influence is everywhere discernible. Chapels are succeeded by synagogues, parish churches are left stranded; Jewish children are being largely enrolled even in the Church schools, and an increasing number of the Board schools are being obliged to adopt Jewish holidays. ${ }^{20}$

Jewish settlement in Spitalfields added a new dimension to an existing connection between the area and endemic criminality. Jewish urban 'delinquency' was particularly associated with both gambling and prostitution, the latter feeding into a potent antisemitic sexual paranoia exploited by anti-migrant campaigners. ${ }^{21}$ A pamphlet on 'Alien Immigration', issued by Conservative Central Office in the build-up to the passing of the Aliens Act in 1905, made explicit the posited transnational relationships between crime and diaspora:

There are in London organised colonies of foreign crime. An alien prisoner, tried at Thames Police Court for picking a pocket, had only been a short time in England, and there was found on him some letters from persons in prisons in 
Russia, in which they declared their intention of joining him as soon as they were released. $^{22}$

Ethnic tensions occasionally manifested themselves in physical confrontation, particularly amongst the young. The oral history of those Jewish men and women growing up in Spitalfields in the late-Victorian and Edwardian periods documents intermittent racial attacks on Jews in the area as well as gang fights (with sometimes fatal consequences) between Jewish and non-Jewish youth and schoolchildren. ${ }^{23}$

In his report on the violence that Brixton experienced in the summer of 1981, Lord Scarman gave a potted history of the area:

Brixton was a lively and prosperous place in the late nineteenth and early twentieth centuries... business and professional people... lived there, some in large dignified houses... Economic decline, however, set in shortly after the First World War, and has continued to the present time. In its appearance and amenities Brixton now shares many of the features of other decaying inner-city areas. $^{24}$

But by the 1960s it was not primarily the gradual structural decay that had begun in 1918 that Brixton was associated with, but the presence of a particular diasporic community in South London, Caribbean migrants who had settled in Britain since the late 1940s. 'Brixton', as a concept rather than a geographical entity, came in the perception of both Caribbean migrants and anti-migration organisations to represent the black post-war experience, and just as the turn-of-the-century East End found itself the epicentre of a national malaise concerning the entry of 'aliens' from Eastern Europe, so the changing nature of South London from the 1950s onwards made Brixton a fulcrum in the debate around New Commonwealth migration. ${ }^{25}$ Like Spitalfields, Brixton became associated with criminal 
activity, and again this was explicitly racialised in anti-migrant discourse. In the early 1970s this area of South London was at the centre of a moral panic surrounding 'mugging', which Enoch Powell, by this point already on the fringes of acceptable politics, characterised as a 'black' crime. ${ }^{26}$ In a Home Office meeting following the 1981 riots, Brixton was described as ‘... a black vice area - a black Soho drawing crime, drugs and prostitution for blacks from all over London' as well as being 'a hotbed of left-wing organisations. ${ }^{27}$

This association between inner South London and crime, deprivation and 'going down in the world' pre-dated Caribbean settlement; in the nineteenth century 'crossing the bridge' (i.e. moving to Lambeth) was a term loaded with negative connotations. ${ }^{28}$ To quote Booth once more: 'South London is different from North, and it is desirable at this point - at the crossing of the river - to make something of a fresh start. The differences between North and South London lie deep. They are historical and physical in origin, but are industrial, social and moral in result... ${ }^{29}$ This social and cultural 'othering' of London south of the river dated at least to the late eighteenth and early nineteenth centuries, linked with the presence of certain noxious and pungent industries in the area such as tanning and the leather trade. ${ }^{30}$ South London and East London thus operated as zones of 'colonial' (i.e. both dangerous and attractive) space long before the settlement of migrants from the former British Empire.

The nature of this space changed significantly over the course of the twentieth century. London underwent profound structural changes, both in the ways in which the state functioned in the capital and in the nature of migrant settlement. What in 1906 had been an imperial hub, the epicentre of an economic and political colossus, had by the 1970s become a 'world city', with a very different role both in a local and an international context. Both the 'imperial capital' and the 'world city' were based around the stratification of 'difference'. But these articulations of 'difference' evolved as the 'others' of the nineteenth and early twentieth centuries, Jews and Irish Catholics, were retrospectively (and only partially) 
brought into a metropolitan narrative that now excluded more recent arrivals from the Caribbean and South Asia. ${ }^{31}$ However, 'sweated' industries in the poorest areas of the capital remained, and, as in the Edwardian period, much of this labour was carried out by migrants. ${ }^{32}$ The ways in which the state in London functioned in a law and order context also experienced important changes between the Edwardian period and the end of the post-war consensus. By the post-war period a significant division existed between the local and central state in London. Most importantly for this discussion, the Metropolitan Police were not under the control of local London authorities. ${ }^{33}$ In response to unrest on the front line in the 1970s and 1980s, the view taken by local political representatives in London (often labelled the 'loony Left' by the tabloid press) differed markedly from that of the centralised state.

Both early twentieth century Spitalfields and the Brixton of the early 1980s were conceptual as well as spatial entities. They represented and served as shorthand for wider social and demographic changes taking place in Britain, some connected with immigration and some incidental to the arrival of new ethnic groups in the city, the 'frontline', for both policing and society. ${ }^{34}$ Spitalfields was a key site for social investigation, middle class outsiders documenting the experiences of the very poor and migrant communities and relaying them to 'respectable society'. William Booth, Charles Booth (and team), and Jack London all visited and wrote about the poorest areas of Spitalfields. 'Caribbean' Brixton attracted sociologists and documentary television crews, attempting to relay and synthesise the experiences of the 'black' proletarian 'other' for the benefit of 'mainstream' 'white' society. ${ }^{35}$ Shelia Patterson and S.K Ruck were the pioneers in this respect, and by the end of the 1970s Brixton was to a degree inundated by researchers attempting to explain the contemporary Caribbean 'problem'. This included a BBC documentary, 'Cause for Concern', filmed in Brixton in the late 1960s on the relationship between the black community and the Metropolitan Police. ${ }^{36}$ 
There were significant contrasts between the diasporic connections that linked Jewish migrants in Spitalfields in the Edwardian period with Eastern Europe and those that connected Caribbean communities in South London with the West Indian islands postSecond World War. For the majority of Jewish refugees the movement from the Pale represented an irrevocable break with their former homeland. A small number might return to Eastern Europe, and many would move on from Britain to America, but there was not the fluidity that characterised the Caribbean diaspora in the 1950s and 1960s, the ability to travel from the Caribbean to Britain and back again. ${ }^{37}$ The Caribbean diaspora also brought with them a four hundred year history of interactions with the British imperial hub that earlier Jewish migrants did not. ${ }^{38}$ The Caribbean post-Second World War was thus, in terms of accessibility and ease of travel, much 'nearer' than Poland and the Ukraine had been in the $1890 \mathrm{~s}$ and 1900s. ${ }^{39}$

Continued diasporic links fed the potency of radical politics. ${ }^{40}$ In Spitalfields various 'international' working men's clubs hosted socialist and anarchist speakers from Eastern and Central Europe, with strong ties both to Russian Jewish socialist groups such as the Bund, and migrant organisations in the cities of the United States. ${ }^{41}$ In Brixton, political turmoil back in the recently decolonised Caribbean islands, particularly Jamaica, and the Black Power movements in the Caribbean and the United States, informed the language of radicalism and resistance as the 1960 s ended. ${ }^{42}$ Social scientists and activists from within the Caribbean community connected the contemporary struggles of black people in Britain with the system of economic and political exploitation inherent in the Caribbean islands that the generation before had left, rooted in a colonial past. ${ }^{43}$

These areas of demographic change became targets for the anti-migrant radical right. The British Brothers' League (BBL) in the early twentieth century, and the National Front (NF) in the 1970s, drew on the tropes of a pre-immigration golden age, before the arrival of the 
'other' precipitated decline, crime and the end of old certainties. The BBL blamed Jews for increasing rents in the East End, undercutting 'British' workers in terms of wages and hours worked, and for various criminal activities, including prostitution and gambling. ${ }^{44}$ In the literature of the NF, Caribbean and Asian communities were again blamed for economic downturn and stealing jobs, and for explicitly racialised 'street crime'. An article in the NF 'youth' journal Bulldog on crime in Lambeth concluded: '... the mugging epidemic is not just an example of ordinary crime, but in fact is a virtual race war being conducted on Whites by Blacks ${ }^{45}$ For Stuart Hall, the response to the 'mugging' moral panic revealed the ideological constructions behind the relations between the state and the racialised 'other' As with the discourse on Jewish crime at the beginning of the twentieth century, there was a strong connection drawn by these anti-migrant groups and the tabloid press between criminality in 'Caribbean' London and criminal gangs in Jamaica and other islands, that exogenous delinquency was being imported into Britain through the networks of diaspora.

The BBL and the NF stressed in their literature the 'othering' of these areas, a particular racially-framed and often sexually-charged interpretation of societal change in the metropolis, and made use of the tropes of invasion and the supplanting of the 'native' in the diaspora space of Spitalfields and Brixton. Cosmo Lang, Bishop of Stepney, referred to Jews as 'locusts', whilst William Evans-Gordon made use of the imagery of the Old Testament to suggest parallels between Jews 'usurping' the Canaanites and other groups in the Bible and the current demographic situation in Spitalfields. ${ }^{46}$

The NF in its literature drew on the racialised and sexualised language of the defunct British imperial project whilst reversing the imagery, with the 'peripheral' 'savage' reversecolonising the 'civilised' 'white' 'hub' through violence. One fascist pamphlet from the late 1970s depicted a gorilla underneath the heading 'Independence for Brixton'. ${ }^{47}$ Animalisation of migrant groups in East and South London was a common theme in proto-fascist and post- 
1945 fascist literature. In both the Edwardian East End and post-war East and South London this polemic was accompanied by provocative meetings and marches and racial violence against minorities.

There were significant differences in the discourse of race as it functioned in the lateVictorian/Edwardian period and its manifestations after the Second World War. The racialisation of Jewish and Irish 'outsider groups' involved a complex nexus of ethnicity, religious prejudice, colonialism and tropes of economic competition. ${ }^{48}$ The construction of the Caribbean 'other' was based primarily on a black/white dichotomy. ${ }^{49}$ Elements of the 'othering' of Jews, such as religious faith and the use of a different language and alphabet, however, were not apparent in the Caribbean case. The significances of the implied cultural and racial 'difference' of Caribbean migrants were interpreted by social scientists in various ways. For Shelia Patterson and Ceri Peach, black 'visibility', as compared to other contemporary 'outsider' groups such as the Irish or Maltese, was crucial. ${ }^{50}$ Peach, writing in 1968, wrote that the wider population considered 'West Indians', Indians and Pakistanis partly as one cohesive demographic because of a 'dark' skin colour. ${ }^{51}$ Sociologists in the 1970s, dissecting the discourse on 'colour', examined the assumptions that the common language and religion shared by Caribbean migrants with the host society made them malleable to an exploitative domestic class system. ${ }^{52}$ It was when black youth began asserting a separate and possibly oppositional alternative culture that the 'problem' of Caribbean youngsters as the 'enemy within' the British state, as described by Stuart Hall, Paul Gilroy and John Solomos, began to dominate the narrative on race. ${ }^{53}$

At the points at which communal anti-police violence broke out, in 1906 and 1981, the outsider status of Jewish and black groups was being reinforced by domestic and international events. In the Jewish case the bakers' strike and the confrontations that followed it took place against the backdrop of renewed persecution in Russia abroad and the passing of 
the Aliens Act at home, the first peacetime legislative restriction of entry into the United Kingdom, and aimed implicitly at Jews. ${ }^{54} 1906$ was also an election year, and anti-Jewish language was used in a notably bad-tempered campaign by both Conservatives and Liberals. ${ }^{55}$

In black and Asian communities the border-line racist rhetoric employed by the Conservative Party in the build-up to the 1979 General Election reinforced the sentiment that, more than thirty years since large-scale migration from the Caribbean and South Asia had begun, non-whites were still 'others', outsider groups living in Britain on sufferance. ${ }^{56} \mathrm{~A}$ Daily Express columnist, writing on 'race' in February 1978, described Caribbean and South Asian populations in the following terms: 'Their faces and beliefs, their way of life are not ours; they are obviously neither our kin nor our kind... Their settlement thus poses a threat to the society we have grown up. ${ }^{57}$ Spitalfields in 1906 and Brixton in 1981 as thematic constructs were effectively demarcated from mainstream national narratives, and the groups that stressed this detachment and 'othering' were not limited to the fringes of the radical right, but included mainstream politicians and political grassroots, the national and local media, and the police.

Attitudes towards the Police and Police attitudes in Spitalfields and Brixton

The oral history of Jews growing up in the Edwardian period demonstrates varied attitudes within East End neighbourhoods towards the local police force, ranging from support to indifference to hostility. Hymie Fagan, who would go on to be a prominent East End communist in the inter-war period, wrote of the bullying presence of the police in immigrant areas before the First World War, where in effect the local force, which he accused of corruption, could act with impunity and without fear of sanctions. Fagan wrote that the local police were 'hated' in working class Jewish neighbourhoods and by Jewish 
market-holders in Whitechapel in particular. ${ }^{58}$ Allegations were also made of the sexual harassment of young Jewish women by individual constables unafraid of the consequences in so targeting a disenfranchised 'other'. ${ }^{59}$ The West End Jewish establishment and the Jewish communal press frequently stressed the good relations between police and Jewish populations, with the reputation Jews enjoyed for being 'law-abiding citizens' contributing to the dominant narrative of a well-behaved, peaceful and well-integrated minority population. ${ }^{60}$ In fact, policing the new Jewish migrant proletariat in the East End presented a significant challenge to the Metropolitan force, and Ben Gidley has written of the impetus controlling the new 'alien' population gave to police techniques such as fingerprinting, surveillance and registering immigrant populations, as well as necessitating the Special Branch having to learn Yiddish. ${ }^{61}$ The imposition of centralised state control in the poorest areas of 'orientalised' East London, Jewish and Gentile, was in its nature substantially different from policing in other areas of the capital. ${ }^{62}$

In the Pale any prolonged interactions with the instruments of the Tsarist state were likely to be negative and harmful; such interactions in the shtetls consequently were conducted through the Landesrabbinat, leading figures of the community who would undertake to deal with the outside world. ${ }^{63}$ This deliberate resistance to the workings of the political and social system continued in the East End, with many Jewish migrants reluctant to have any dealings with the machinery of the British state, to the extent of refusing to complete census returns. ${ }^{64}$ Interactions with the police at a local level were also minimised, and, as with Irish East End communities of the generation before, if trouble or transgressions could be dealt with within the community rather than through the British legal system, they were done so. ${ }^{65}$

In the Jewish context police harassment was centred on involvement in radical politics. In 1885 and 1889 the Berner Street Club in the East End, a key meeting point for 
Jewish socialists and anarchists, was raided by the Metropolitan force, and it was alleged that the police had incited antisemitic rioting against the radicals, followed by police brutality during interrogation against those taken into custody, including an assault on one prisoner with a poker. The anarcho-socialist paper Commonweal described the 1885 attack in the following terms:

The windows were smashed, and the police with drawn truncheons forced their way into the club room, accompanied by a number of plain-clothes men and a mob. The members were at once assaulted by the police and the premises ransacked. One member, on appealing for protection to a policeman was told he would be protected with this - and a truncheon was thrust in his face... ${ }^{66}$

In effect the police were here using colonial methods of policing, adopting tactics that would have been unacceptable in the capital outside of the class and ethnic contexts of diasporic Whitechapel, but would be familiar to those who had studied (or experienced) police tactics in the imperial peripheries. ${ }^{67}$ The violence used by the Metropolitan Police to break up the Berner Street meetings, coupled with more frequent and low level police harassment against foreign radicals generally and Jews in particular left a latent but persistent legacy of bitterness in the East End that would manifest itself in physical attacks on police during periods of industrial unrest in the early twentieth century.

Jewish radicals in turn-of-the-century Spitalfields avoided interactions with the police where possible; Caribbean youth in post-consensus South London did not have the choice: Robert Moore in Racism and Black Resistance (1975) wrote that:

The police also seem to overact to incidents involving black people. Thus a constable approaching a group of loitering youths may radio for help, and the arrival of police cars and more constables result in a crowd gathering, jostling and 
arguments - and charges. In fact these situations look very much like police riots. The best we can say about these situations is that the arrival of the police in force is itself highly provocative. ${ }^{68}$

The lack of black police officers in London in the early 1980s was apparent in Brixton, with a Caribbean community forming some 25 per cent of the total population, Scarman put the number of black officers serving in the Metropolitan Police in October 1981 as 132, or 0.5 per cent of the total strength of the force ${ }^{69}$ Patterson had noted this demographic disparity between police and policed in South London as early as $1963 .^{70}$ Jewish refugees from Eastern Europe had brought with them a distrust of the representatives of state power; for Caribbean migrants disillusionment with the police did not take long to set in. Rosie Wild traces this to the violence of 1958, the failure of the police to protect black communities against racist attacks in Nottingham and Notting Hill, and the inadequate response to the racist murder of Kelso Cochrane in 1959. ${ }^{71}$ By the 1970s relationships between the Metropolitan Police and black communities, by no means limited to youth, had deteriorated to such a significant degree that one could speak of a complete breakdown in relations between police and population in Brixton, and the effective end of 'policing by consent' in diasporic working class South London. Darcus Howe framed the tactics adopted by the police in London postSecond World War as essentially colonial in character, describing black neighbourhoods being policed as 'domestic colonies'. ${ }^{72}$

Just as Jewish socialists and Caribbean youth viewed the police as an alien force more or less predisposed against them, the police also had entrenched views of the minorities they were policing. Whilst it was the opinion of elements of the Metropolitan Police that Jews were not 'man enough' to be violent in day to day life, feeding into a long-established idea of Jewish weakness and effeminacy, political violence was another matter. ${ }^{73}$ In anti-migrant Edwardian discourse 'Jew' and 'anarchist' were almost synonymous, and one of the key 
motivating factors behind the Aliens Act of 1905 was the demand to be able to stop foreign (Jewish) 'subversives' from settling in Britain. ${ }^{74}$ More broadly, the origins of the migrants were viewed as primitive, backwards and brutal, a peasant society of autocracy, superstition and pogroms, which Jews were escaping from and yet simultaneously embodying. The Pale of Settlement itself operated as semi-colonial space, like colonial Africa or the Pacific an area of 'darkness' and potential violence, with the customs, traditions and language brought over from that space a barrier to the comprehension and acceptance of the host society. ${ }^{75}$ The colonial system in Tsarist Russia, a contiguous land empire which practiced an institutionalised victimisation of religious minorities, differed from the British imperial project, based on racial stratifications in imperial peripheries. Jewish refugees arriving in the East End were thus exchanging an area of religious discriminatory semi-colonial space, the Pale of Settlement, for the 'othered' space of Spitalfields. By the time the first generation of London-born children of post-war Caribbean migrants were becoming adults the British imperial project had significantly altered; the 'co-operative' narrative of Commonwealth had replaced that of Empire.

Empire-based tropes of 'savagery' however remained potent into the Commonwealth period. Black youth were associated by police and press with various forms of violence, as well as being vulnerable to 'exploitation' by radical leftist or black power groups. The annual confrontations between the black community and the police in London at key events such as the Notting Hill Carnival from 1976 onwards confirmed for the police the association between Caribbean teenagers and disorder. ${ }^{76}$ That black youths were preternaturally violent continued to be a familiar trope in the discussion of 'race relations' into the 1980s. A chapter by the sociologists Ernest Cashmore and Barry Troyna in the 1982 collection of essays Black Youth in Crisis, written in the aftermath of the Brixton and Toxteth disturbances, made the 
claim that: ... whatever the source of this violent proclivity, there can be no denying its existence: black youth do have a certain fascination for violence. ${ }^{, 77}$

The introduction to the same collection wrote of the 'dishonesty and arrogance' of black youth. ${ }^{78}$ These ideas of inherent black violence and the binary oppositions white/black, peaceful/disruptive and civilised/savage had their roots in the British colonial experience; the racialised dialogue of the post-war period continued to draw on the imagery of the Empire and the implicit inferiority of non-whites. ${ }^{79}$ The Metropolitan Police, taking as a given that rapidly-escalating confrontation with black teenagers at intersections such as the 'front-line' in Brixton would follow engagement, pre-empted and guaranteed this symbiotic antipathy by their own aggressive tactics. The police themselves resented the hostility they faced on the ground in Brixton, thus exacerbating the breakdown of 'policing by consent' and polarisation between centralised state and citizens. ${ }^{80}$

Both the 1900s and the years following the breakdown in the post-war consensus had something of an 'end of days' quality about them; in 1906 and 1981 an apocalyptic frisson was apparent in societal relations, the build-up to an expected confrontation between political and social groupings with fundamentally different visions of Britain, and a rejection of compromise or negotiation. The Edwardian period was characterised by societal violence, between strikers and strike-breakers, violence by those fighting for and opposed to female suffrage, and violence in Ireland. Politics in the post-consensus United Kingdom of the 1970s and 1980s were also imbued with a sense of the legitimacy of the use of physical force to achieve political goals. From 1969 onwards Northern Ireland had descended into something approaching civil war, images of rioting youths and children throwing petrol bombs at British soldiers being broadcast nightly into British homes, with the Home Office and the police acutely aware of the possible effects this might have on disenchanted youth on the other side of the Irish Sea ${ }^{81}$ The police themselves began to adopt on British streets some of the tactics 
of the Royal Ulster Constabulary in the form of the Special Patrol Group (SPG), an organisation formed in the early 1960s but that came into its own as the 1970s drew to an end. ${ }^{82}$ The SPG would take the lead in the operation in Brixton that sparked the violence of the summer of 1981 .

Anti-state violence in Spitalfields and Brixton

The violence in Spitalfields in 1906 had its roots into two separate long-term areas of social tension taking place within the same spatial confines. Most immediately it grew out of class conflict and unionisation in the 'sweated' trades of the East End, in which Jewish migrants worked - tailoring, boot-making and cabinet-making. The 1890s and 1900s were a period of severe communal class tensions within the Jewish East End, with industrial action in the tailoring industry in 1889 and 1906, in cabinet making in 1896 and 1900, and in bootmaking in 1891 and $1901 .{ }^{83}$ In 1904 and then again in 1906 Jewish bakers joined their comrades in the sweated trades in staging walkouts and picketing the premises of 'sweated' employers. ${ }^{84}$ These bakeries were a central part of Jewish East End communities - the challah, bagels, pastries and Russian black bread sold in these shops maintaining a culinary and cultural connection with Eastern Europe. ${ }^{85}$

The second factor behind the anti-police rioting of 1906 lay in a long-term antipathy towards the Metropolitan force by local non-Jewish inhabitants of Spitalfields. If Jewish EastEnders had a suspicion of the police tied in with the situation they or their parents had experienced in the Pale of Settlement, a significant proportion of non-Jewish residents, English and Irish, had a violent and long-running aversion to the forces of law and order ${ }^{86} \mathrm{At}$ the turn of the twentieth century violence against police constables involving large groups of people was a regular occurrence, sometimes with fatal results. Often this was precipitated by an attempted 'rescue' following an arrest, when the crowd would attempt to detach the person 
taken in charge by the police by physical force ${ }^{87}$ Indeed, a 'rescue' would be the catalyst for the proliferation of the violence of August and September 1906.

The precipitating event for the unrest of the autumn of 1906 was a physical assault by an employer on an employee, both Jewish. Jewish bakers in the area had been on strike for some time, after a master baker, Mr S. Levy, had refused a wage increase for the foreman of his bakery. The mainly Jewish workers called a strike, which the employers subsequently claimed had been motivated by a refusal on the part of Jewish bakers to work with non-Jews. This claim was refuted by the Jewish Bakers' Union, whose chairman, Hyman Morgenstein, later described the charges as a 'complete fabrication', and pointed to the large number of Gentiles who were in the union, including the vice-chairman and the foreman whose illtreatment had brought on the strike in the first place. ${ }^{88}$

By mid-August pickets had broken out across Spitalfields urging Sunday shoppers not to buy 'scab bread'. Outside Levy's bakery 'Russian, Polish and German bakers had practically taken possession of the street. ${ }^{89}$ One striker, Hyman Boekbinder, ended in up in an altercation with Levy, and blows were exchanged. Boekbinder subsequently commenced 'haranguing a large crowd in Yiddish' and verbally abusing the baker. ${ }^{90}$ It was then alleged that Boekbinder attempted to smash the windows of the bakery. At this point a constable attempted to arrest the striker, who was then rescued by the large crowd, most of whom were not bakers and which was a mix of Jews and non-Jews, that had gathered; at this point 'the mob of 100 increased to four or five times that number. ${ }^{91}$ Boekbinder then succeeded in smashing some of the windows of the shop, by which time police reinforcements had been called in, and there followed a general confrontation between the crowd and the police. Over the next fortnight anti-police and anti-employer violence spread across Spitalfields. The Jewish World reported serious physical altercations between masters and bakers, and that a 
man had died from blows received during the unrest. ${ }^{92}$ The picketing of bakeries now involved thousands of people. The violence worsened as the strike continued in September:

Serious riots broke out in East London this week in connection with the strike amongst the bakers... the whole of the district between Commercial Street and St George Street became a pandemonium. Men and women joined in the riot, and [attacked shops], the windows of which were broken wholesale. When a constable interfered the crowd, which was wholly composed of foreigners, started upon him and a fierce struggle ensued. The constable arrested one baker, and in the struggle had his fingers severely bitten, two of them being almost severed. ${ }^{93}$

This anti-police violence then spread across Spitalfields, with serious attacks on the police in the Flower and Dean Street area. ${ }^{94}$ Whilst the genesis of the Spitalfields riots lay in the latent class tensions apparent in the Jewish community, what it evolved into, a general assault on the police in the area, was inter-communal, involving predominantly non-Jews.

The Brixton violence of 1981 also had as its precipitate immediate cause the attempted 'rescue' of a young man from the custody of the police. A young black man, Michael Bailey, had been stabbed in an altercation on the high street. The police attempted to get Bailey out of the area to receive medical attention, but the crowd that had gathered assumed the youth was being arrested or even assaulted, and attempted to detach him from the Metropolitan force. The confusion was symptomatic of the relationship between young people in Brixton and the police, that in Scarman's words 'the worst construction was frequently put upon police action, even when it was lawful, appropriate and sensible. ${ }^{95}$ Tensions had increased dramatically in a short space of time in relation to a new initiative against street crime in South London by the Metropolitan Police, the provocatively named 'Swamp 81 '. ${ }^{96}$ On the Brixton 'front-line' of Atlantic Road and Railton Road a standoff developed between people 
and police as, as in 1906, rumour and curiosity coupled with long-term resentment brought (especially young) people from around South London to the area of confrontation. ${ }^{97}$ Over the weekend of April 10 to 12 Brixton experienced mass communal violence, directed against the Metropolitan Police. There were no deaths, but hundreds of injuries, great destruction of property, and no sign of any prospects of bridging the chasm that was evident between police and people.

The popular press portrayed Brixton as a 'race riot', true to the dominant narrative of the area as a post-colonial spatial and ethnic 'other'. ${ }^{98}$ But this was immediately contested by other contemporary observers, including the Home Office. In an internal memorandum immediately after the riots, the unrest was described in the following terms:

The present violent reaction, damage and looting is... not entirely a racial one though there is a racial element, and in any event extremists (black or white) will persist in finding a racial bias. But black and white are reacting; there is an imitative element; and the factors of unemployment, urban deprivation, idleness, lack of hope for the future, changing attitudes towards authority and greater expectations, and lack of parental influence, are all mixed together for black and white... ${ }^{99}$

Tony Bunyan, writing in Race and Class, described what occurred in Brixton and other cities as an alliance between 'the black communities and the dispossessed white working class.' ${ }^{100}$ Inter-ethnic sympathy was not entirely generational or class-based. There was significant support for the struggle of youth with the police, if not for actual physical violence, from the more prosperous middle class and middle aged inhabitants of Lambeth, black and white, such as teachers, social workers and trade union organisers, tapping into an 
older socialist heritage of conflict with the police that stretched back to Cable Street and the memories of the 1930s. ${ }^{101}$

In addition to suggestions by Scarman and others that avarice played a part in the participation of outsiders, was the claim that the youth of Brixton were being manipulated by far-left groups. Scarman wrote of a white woman 'with an American accent', acting as spokesperson for the rioters, and of the police claiming that 'A white man and a black youth appeared to one officer present to be directing operations. ${ }^{102}$ It was claimed that 'revolutionary' white outsiders had instructed the youth of Brixton in how to make and store petrol bombs. ${ }^{103}$

The Anglo-Jewish hierarchy had consistently argued from the 1890s onwards that external socialist and anarchist agitators were manipulating a naïve immigrant proletariat. ${ }^{104}$ An editorial in the Jewish World during the worst of the 1906 violence recognised the partial legitimacy of the strikers' demands, but disavowed the means in which they were expressed:

We have always adopted a sympathetic attitude towards the needs and condition of our co-religionists who reside in our 'near east'. We have likewise accorded and shall continue to accord support to the efforts of working men and women who strive to improve oppressive conditions of labour. We must confess, however, that we read with some dismay of the attempted rescue by Jews of men who had been arrested by the police for breaches of the peace. Jews generally have the reputation of being law-abiding citizens, and such action is greatly to be regretted. $^{105}$

This article makes explicit the orientialisation of East End Jewry ('our near east') by a middle class Jewish communal press. In terms of the narrative of the 'respectability' of a minority being jeopardised by communal violence, similar sentiments were expressed in a letter from 
the chairman of the National West Indian Conservative Society to the Home Office following the Brixton disturbances, which described the violence as '... ugliness as you and I would have hoped never to encounter' and laid the blame for the violence on a number of far-left groups:

... I am convinced that part of this trouble - and indeed a large part of it - is the direct result of deep-rooted Socialism and the political activists are not prepared to let it die down until they have drained every drop of blood from the situation. $^{106}$

Rioting was thus framed as simultaneously 'mindless' and purposeful, avaricious hooliganism by the rioters and deliberate political subversion on the part of the 'agitators' fuelling the discontent. One key difference in the two case studies was the role played by trade union organisations in the violence. 1906 was the product in part of the rise of an increasingly confident labour movement operating in the diasporic East End. In Brixton, by contrast, trade unions, as opposed to far-left pressure groups, played no significant role, beside some moral support by local activists. In 1981 unemployment in communities, rather than poor working conditions, was a factor in the build-up to the violence. Both in 1906 and 1981 anti-police sentiment and action had germinated in the context of the specific concerns of a minority group targeted by the police that, over the course of the actual violence, expanded to encompass inter-ethnic, inter-class and inter-generational hostility towards the state and a broader expression of dissatisfaction with the social, economic and political status quo. In both Spitalfields in 1906 and Brixton in 1981, as Michael Keith suggested in a 1987 essay on the riots of the early 1980s, there were two qualitatively different manifestations of violence which overlapped, one with specific objectives in immediate response to a particular situation (police attempting to break up pickets during a strike or an oppressive stop and 
search policy), and the other a broader and less politically coherent response to a general break down in law and order, which included looting as well as anti-state violence. ${ }^{107}$

After the violence

Both Spitalfields and Brixton continued to function as conceptual as well as spatial entities well after the uprisings/rioting documented above, and the violence of 1906 and 1981 in the short-term reinforced the 'othering' of these areas, where apparently the writ of law did not extend, and where 'wild' Eastern European Jews or Caribbean youth could confront the forces of the state without restraint or apparent sanction. The violence that occurred reinforced views that such spaces were dangerous, not only in terms of the possibility of crime or assault committed against the person of the respectable interloper or the policeman who ventured into these zones, but as zones where a minority, through exclusion from wider society and 'ghettoization', had formed a majority within a confined spatial area, subverting a wider colonial or post-colonial order that marginalised such groups. Whether 'East of Aldgate', 'Over the Bridge' or 'South of the River', the 'Jewish' East End or 'Caribbean' South London functioned as geographical and societal 'others' to a mainstream society and state that was represented on the ground by the Metropolitan Police and partly self-defined by a belief in the principle of policing by consent. ${ }^{108}$ Anti-police violence was a challenge to this assumption.

The association of both groups with violence was bolstered in the aftermath of the disturbances of 1906 and 1981. The Houndsditch murders and the Sidney Street siege of 1910-11, in which three policeman were murdered and then a number of 'anarchists' subsequently immolated was blamed (wrongly) on East End Jewish revolutionaries. ${ }^{109} \mathrm{~A}$ poem published in the local press on the Houndsditch murders included the couplet 'What's 
the good of an Aliens Act, when we let the Alien scum, swarm into England in droves, and herd in every city slum. ${ }^{, 10}$

As regarded Brixton the far-right continued to stress that this was a zone of exclusion, in which whites were not welcome, that 'reverse-colonization' on a large scale had taken place, and that the solution was enforced repatriation. ${ }^{111}$ Enoch Powell repeated these demands in Parliament. The fascist and Powellite discourse was partially echoed by elements of the Conservative Party, and the right-wing press, with the Daily Mail also referring to repatriation as a response. ${ }^{112}$ On the left, the Labour Party stressed social deprivation, poor housing and societal ghettoization, and long-term structural unemployment as reasons behind the violence; the trade unions and the churches also emphasised social conditions and moral disconnection. ${ }^{113}$ For social scientists 1981 constituted both a culmination and a confirmation of debates about race and the state that had been going on since the late 1960s. It also produced a new wave of ground-breaking sociological investigation. The Metropolitan Police meanwhile continued to stress an unproblematic narrative of criminality and necessary responses. ${ }^{114}$

Despite the decline of the NF in the early 1980s racial violence against minority groups continued. In a sociological survey implemented by the Policy Studies Institute and drawing on interviews carried out between 1979 and 1984, it was reported that racial attacks on minorities were in fact increasing in Britain in the first half of the 1980s, and that there was a widespread lack of confidence in the will of the police to investigate and prosecute attacks of a racial nature. ${ }^{115}$

The violence of 1906 and 1981 did not constitute the final chapters in the narrative of physical confrontation between working class Jewish or black communities and the police. There would be renewed conflict between trade unionists, both Jewish and Gentile, and the 
Metropolitan Police in the East End during the industrial unrest of 1911-12. The crosscommunal nature of the anti-police violence of 1906 would be repeated, again on a much larger scale, in October 1936 at Cable Street, subsequently depicted as the highpoint of classbased ethnic cooperation between the English, Irish and Jewish working classes. ${ }^{116}$ The extent of this cooperation has been contested, and the scale and the nature of inter-ethnic interactions in response to the British Union of Fascists has been partially mythologised and romanticised. ${ }^{117}$ But if nothing else, 1936 indicates a continued antipathy towards the police in the East End that was inter-communal in nature. The rise of fascism in the East End in the 1930s also added a new dimension to relationships between the police and the Jewish community, with allegations of police partiality towards and support for the sentiments expressed by fascist speakers at political meetings. ${ }^{118}$ What differentiated 1906 from both 1911-12 and 1936 was the unfocused nature of the wider communal anti-police violence following the industrial action of the bakers in 1906, as opposed to the explicitly politicalised goals of the tailors' strike and the anti-fascist action of Cable Street. Cable Street also led to the foundations of modern legislation against public articulations of prejudice, the Public Order Act, which in turn formed the basis of anti-hate speech government legislation from the 1960s onwards. ${ }^{119}$

In Brixton there would be serious police-public violence in 1984, 1985, 1995 and 2011. In terms of damage and injuries the violence of 1985 was more severe than that of 1981. Reactions by government and media to the events of 1985 lacked the introspection on both the mainstream right and the left that followed the Scarman Report, and that made the disturbances of 1981 representative of a sea-change in perceptions of poverty and disenfranchisement in modern Britain. The violence of 1985 instead was blamed straightforwardly by the right-wing press and government on (explicitly racialised) avaricious criminality. ${ }^{120}$ The Scarman Report had identified areas of conflict and resentment between 
the police and black communities, and posited some solutions, but the mutual antipathy that existed, and had existed for a generation, was too severe to be healed in the short or even medium term, and the disproportionate targeting of non-white individuals by the police remains an issue in the second decade of the twenty-first century. ${ }^{121}$

Both militant East End Jewish trade unionism and the insurrection of black youth in South London in 1981 have retrospectively been brought back into the Jewish and Caribbean diasporic national narratives of settlement and the forging of 'black British' or 'AngloJewish' identity. The turn-of-the-century East End Jewish communities, and particularly Jewish socialists and trade unionists, for so long the 'poor relations' side-lined in the narrative of successful, prosperous and peaceful assimilation, were retrospectively moved from the periphery to the centre of the Jewish experience, to a significant degree now posthumously depicted as the pioneers of the modern Anglo-Jewish story. ${ }^{122}$ Similarly, the retrospective interpretation of the events of Brixton in 1981 has evolved from a narrative of 'out of control' second generation Caribbean youth disgracing a community to embodying an external manifestation of a cultural and political sea-change in British society, where a marginalised group, no longer prepared to accept harassment and second-class status, staked a forcible claim to equality and consideration by the wider population, the political establishment, and the forces of law and order. ${ }^{123}$ 'Jewish' Spitalfields and 'Caribbean' Brixton remain conceptual as well as spatial entities (indeed 'Jewish' Spitalfields is now almost solely a conceptual entity) but these associations between space and the struggles of subaltern minority groups against the state are now framed within the discourse of resistance and self-assertion rather than delinquency and subversion.

\footnotetext{
${ }^{1}$ The National Archives (henceforth TNA) HO/376/235 Internal Home Office Report, 13 July 1981.
} 


\footnotetext{
${ }^{2}$ McGuinness, 'Geographies with a difference?', 100-101.

${ }^{3}$ Conteh-Morgan, Collective Political Violence, 16. See Keith, Race, Riots and Policing, 53 for the etymology of the 'riot'/'uprising' and Keith, 'Something Happened' 278-280 on the imputation of the irrationality of the
} riot in contemporary coverage of civil disturbances.

${ }^{4}$ See Eric Hobsbawm on collective bargaining through crowd violence, Charles Tilly on the processes and motives of collective violence and Donald L. Horowitz on ethnicity, mass violence, and the 'pattern' of the riot. ${ }^{5}$ Brah, Cartographies of Diaspora.

${ }^{6}$ See Peach, (ed.), Urban Social Segregations, Burgess and Gold (eds.) Geography, The Media and Popular Culture, Jackson (ed.) Race and Racism, Bressey and Dwyer (eds.) New Geographies of Race and Racism. For an overview of the evolution of human geography and 'race' from the 1970s to the mid-1990s see Bonnett, 'Constructions of 'race'.

${ }^{7}$ Bonnett, 'Constructions of 'race" 875.

${ }^{8}$ See Keith, Race, Riots and Policing, 20, for discussion of 'front-lines' in 1980s London and 26-27 for the differing interpretation of what the 'front-line', in Brixton, Dalston or Notting Hill, in fact constitutes, alternately (depending on perspective) a centre of the communal spirt, a centre of crime, or a centre of resistance.

${ }^{9}$ Kershen, 'The migrant at home in Spitalfields: Memory, myth and reality', Davis, 'From 'Rookeries' to 'Communities' and Glynn 'East End immigrants and the battle for housing'.

${ }^{10}$ Rowe, The Racialisation of Disorder, 24, and Jackson 'Afterword'.

${ }^{11}$ Jackson, 'The idea of "Race" and the geography of racism' in Jackson (ed.) Race and Racism, 8.

${ }^{12}$ See Bagguley and Hussain, Riotous Citizens for an overview of the summer of 2001.

${ }^{13}$ May, 'Globalization and the Politics of Place'

${ }^{14}$ Watt, 'Respectability, Roughness and "Race"”

${ }^{15}$ Brooke, 'Space, Emotions and the Everyday'

${ }^{16}$ See Fishman, East End 1888, chapter seven and Walkowitz, City of Dreadful Delight

${ }^{17}$ Booth, Poverty, Vol. I, 31-32.

${ }^{18}$ White, Rothschild Buildings, 132-133 and Gilroy, There Ain't No Black in the Union Jack, 77.

${ }^{19}$ Holmes, Anti-Semitism in British Society, 18. Feldman, ‘The Importance of being English' 56.

${ }^{20}$ Booth, Charles, Religious Influences, Vol. II, 4.

${ }^{21}$ Banister, England Under the Jews, 39.

${ }^{22}$ Alien Immigration - Issued by the Conservative Central Office, Report of the Royal Commission on Alien Immigration, Extracts from the evidence given before Royal Commission and from the Commissionaires Report, 9. My emphasis.

${ }^{23}$ The Jewish Chronicle, 25 March 1898. See interviews held at the Jewish Museum, Camden. Englander, 'Booths Jews', 305.

${ }^{24}$ Scarman, The Scarman Report, 18-19.

${ }^{25}$ See Burgess, 'News from Nowhere' 21 'The decaying mansions ideologically chart the decline of the area from bourgeois suburb to working class slum and black ghetto'. 
${ }^{26}$ Roberts, 'The debate on Sus', 105. See Hall et al Policing the Crisis on the creation of the 'mugger' as 1970s folk-devil and the Victorian roots of this particular moral panic.

${ }^{27}$ TNA HO/376/235/20 Meeting of Mr Brennan with representatives of the probation services from riot areas, 15 July 1981.

${ }^{28}$ Gibson-Brydon, Moral Mapping, 104.

${ }^{29}$ Booth, Charles, Religious Influences, Vol. IV, 3.

${ }^{30}$ Inwood, A History of London, 456-458.

${ }^{31}$ Eades, Placing London, 11, 170.

${ }^{32}$ King, Global Cities, 28, 143.

${ }^{33}$ Inwood, A History of London, 709, 750-751.

${ }^{34}$ Ceri Peach quoted in Sivanandan, Race, Class and the State, 349.

${ }^{35}$ See Hall, Stuart, 'New Ethnicities' in Hall, Stuart, Morley, David and Chen, Kuan-Hsing, Stuart Hall:

Critical Dialogues in Cultural Studies. London: Routledge, 1996, on cinematic representation of the black experience, (See Keith, Race, Riots and Policing, 27)

${ }^{36}$ Howe, From Bobby to Babylon, 27-30.

${ }^{37}$ Nanton, 'The Caribbean Diaspora in the Promised Land' 114.

${ }^{38}$ Nanton, 'The Caribbean Diaspora in the Promised Land' 112.

${ }^{39}$ See Perry, London is the Place for Me, 58-60 on mobility in the Commonwealth and the choices of destination made by Caribbean migrants.

${ }^{40}$ Schwarz, 'Claudia Jones and the West Indian Gazette' 280 and Perry, London is the Place for Me, 131-132for the Caribbean diasporic radical context

${ }^{41}$ Rocker, The London Years, 66.

${ }^{42}$ See Wild, 'Black was the colour of our fight'. Howe, From Bobby to Babylon, .37-38, Angelo, 'The Black

Panthers in London'

${ }^{43}$ Gilroy 'You Can't Fool the Youths', 208, and Howe, Bobby to Babylon, 20-21.

${ }^{44}$ Bermant, Point of Arrival, 141-142.

${ }^{45}$ Bulldog, 10 May 1980.

${ }^{46}$ Evans-Gordon, The Alien Immigrant, 12.

${ }^{47}$ Blood on the Streets, 94.

${ }^{48}$ See Holmes, Anti-Semitism in British Society and Julius, Trials of the Diaspora.

${ }^{49}$ Pilkington, Racial Disadvantage and Ethnic Diversity in Britain, 25, 48, 180.

${ }^{50}$ Patterson, Dark Strangers, 179, 195.

${ }^{51}$ Peach, West Indian Migration, p.xvii.

${ }^{52}$ Institute of Race Relations, Race, Class and the State, 360-361

${ }^{53}$ Solomos, Black Youth, 204, 216.

${ }^{54}$ See Gainer, The Alien Invasion.

${ }^{55}$ The Jewish World, 19 January 1906.

${ }^{56}$ Sivanandan, 'From resistance to rebellion', 145.

${ }^{57}$ The Daily Express, 02 February 1978. 
${ }^{58}$ People's History Museum, Manchester, CP/IND/FAG/1/5 'Childhood Memories of Hymie Fagan', Unpublished Autobiography.

${ }^{59}$ Taylor, 'Cass, Coverdale and Consent', 129.

${ }^{60}$ The Jewish World, 19 January 1906. See Tananbaum, "'Morally Depraved and Abnormally Criminal", 115.

${ }^{61}$ Gidley, 'Citizenship and Belonging' 56 and Englander, A Documentary History of Jewish Immigrants, 82-83.

${ }^{62}$ See Walkowitz, City of Dreadful Delight, and Ahmed, 'Historicising Diaspora Spaces', 55.

${ }^{63}$ Alderman, Modern British Jewry, 38.

${ }^{64}$ The Jewish Chronicle 25 June 1890.

${ }^{65}$ See Van Onselen, 'Jewish police informers in the Atlantic world', 123.

${ }^{66}$ Commonweal, June 1885.

${ }^{67}$ Anderson, Policing the Empire.

${ }^{68}$ Moore, Racism and Black Resistance, 65-66.

${ }^{69}$ Scarman, Scarman Report, 122.

${ }^{70}$ Patterson, Dark Strangers, 82-83.

${ }^{71}$ Wild, 'Black was the colour of our fight', 35.

${ }^{72}$ Howe, From Bobby to Babylon, 16.

${ }^{73}$ Feldman, Englishmen and Jews, 285, See Keith on police masculinity in Race, Riots and Policing, 206.

${ }^{74}$ See Glover, Literature, Immigration, and Diaspora in Fin-de-Siècle England. .

${ }^{75}$ See Feldman, 'Jews and the British Empire, c.1900'.

${ }^{76}$ Keith, Race, Riots and Policing, 123-124. See Tilly, The Politics of Collective Violence, 84, on the role of 'violent rituals' in state-people violence. Jackson, 'Street Life', 214, discussed the role of 'Carnival' in the Caribbean and London.

${ }^{77}$ Cashmore and Troyna 'Black youth in crisis', 33.

78 'Introduction' in Black Youth in Crisis, 3.

${ }^{79}$ See Rowe, The Racialisation of Disorder, 176 for black and white 'binaries' at work in racialised discourse, Hall, 'New Ethnicities', 445 on the 'Other', Gordon and Rosenberg (eds), Daily Racism 65-70.

${ }^{80}$ Keith, Race, Riots and Policing, 130, 163-164, See Gilroy, 'Police and Thieves'.

${ }^{81}$ TNA HO/376/235 Inner City Violence - Note by the Research Unity, July 1981.

${ }^{82}$ Salway, Reading the Riot Acts, 13.

${ }^{83}$ White, Rothschild Buildings, 94.

${ }^{84}$ Fishman, East End Jewish Radicals, 253.

${ }^{85}$ White, Rothschild Buildings, 111.

${ }^{86}$ August, 'A culture of consolation?', 208-209.

${ }^{87}$ Bunyan, 'The police against the people', 157.

${ }^{88}$ The Jewish World, 07 September 1906.

${ }^{89}$ The East London Observer, 18 August 1906.

${ }^{90}$ The Jewish Chronicle, 17 August 1906.

${ }^{91}$ The East London Observer, 18 August 1906.

${ }_{92}^{92}$ The Jewish World, 07 September 1906. 
${ }^{93}$ East London Observer, 08 September 1906.

${ }^{94}$ East London Advertiser, 22 September 1906 in White, Rothschild Buildings, 127.

${ }^{95}$ Scarman, Scarman Report, 45.

${ }^{96}$ Salway, Reading the Riot Acts, 32.

${ }^{97}$ See Horowitz, The Deadly Ethnic Riot, 74 on the importance of the rumour before communal violence.

${ }^{98}$ Gordon and Rosenberg, Daily Racism, 18-19.

${ }^{99}$ TNA HO/376/235/19 'Recent Disorders', July 1981.

${ }^{100}$ Bunyan, 'The People Against the Police', 153.

${ }^{101}$ Salway, Reading the Riot Acts, 36.

${ }^{102}$ Scarman, Scarman Report, 54-56.

${ }^{103}$ Scarman, Scarman Report, 75-76.

${ }^{104}$ The Jewish Chronicle, 05 June 1891.

${ }^{105}$ The Jewish World, 07 September 1906.

${ }^{106}$ TNA HO/376/240/45 letter from the National West Indian Conservative Society to Mervyn Kohler, 21 April 1981.

${ }^{107}$ Keith, 'Something happened' in Jackson (ed.) Race and Racism, 286.

${ }^{108}$ Thurmond Smith, Political Policing, 202, Petrow, Policing Morals, 30.

${ }^{109}$ Bloom, Violent London, 250-252.

${ }^{110}$ London Metropolitan Archives ACC/3121/B/02/011.

${ }^{111}$ National Front News, May 1981.

${ }^{112}$ Solomos, Black Youth, 228.

${ }^{113}$ Benyon, John 'The Riots, Lord Scarman and the Political Agenda' in Benyon (ed.) Scarman and After, 4-5.

${ }^{114}$ Murdock, Graham, 'Reporting the Riots: Images and Impact' in Benyon (ed.) Scarman and After, 90.

${ }^{115}$ Brown, Black and White Britain, 257-258.

${ }^{116}$ Jacobs, Out of the Ghetto, 257.

${ }^{117}$ See Kushner, Tony, "'Long May its Memory Live!" Writing and Rewriting "the Battle of Cable Street" in Kushner and Valman (eds.) Remembering Cable Street.

${ }^{118}$ Lebzelter, Political Anti-Semitism in England, 120-127.

${ }^{119}$ Hilliard, 'Words that Disturb' 787.

${ }^{120}$ Solomos, Race and Racism, 161.

${ }^{121}$ See McGhee, Intolerant Britain?, chapter one for discussion of the continuing criminalisation of young people of Caribbean descent.

${ }^{122}$ Kushner, 'The end of the 'Anglo-Jewish' progress show', 83.

${ }^{123}$ See Keith, Race, Riots and Policing, 164, on the indelible association after 1981 of 'Brixton' with 'the relationship between Black people and the police'.

\section{References}

Ahmed, Nazneen 'Historicising Diaspora Spaces: Performing Faith, Race and Place in London's East End' in Garnett, Jane and Hausner, Sondra L., Religion and Diaspora. Basingstoke: Palgrave MacMillan, 2015

Alderman, Geoffrey, Modern British Jewry. Oxford: Clarendon Press, 1992 
Anderson, David, Policing the Empire: Government, Authority and Control. Manchester: Manchester University Press, 1991

Angelo, Anne Marie, 'The Black Panthers in London, 1967-1972: A Diaspora Struggle Navigates the Black Atlantic' Radical History Review, no.103 (Winter 2009)

August, Andrew, 'A culture of consolation? Rethinking politics in working class London, 1870-1914' Historical Research, Vol.74, No. 184 (May 2001), pp.193-219

Bagguley, Paul and Hussain, Yasmin, Riotous Citizens: Ethnic Conflict in Multicultural Britain. London:

Routledge, 2016

Bermant, Chaim, Point of Arrival: A Study of London's East End. London: Eyre Methuen, 1975

Blood on the Streets: A Report by Bethnal Green and Stepney Trades Council on Racial Attacks in East London. London: Bethnal Green and Stepney Trades Council, 1978

Benyon, John (ed.) Scarman and After: Essays Reflecting on Lord Scarman's Report, the Riots and their Aftermath. Oxford: Pergamon Press, 1984.

Bloom, Clive, Violent London. London: Pan Macmillan, 2004

Bonnett, Alastair, 'Constructions of 'race', place and discipline: geographies of 'racial identity' and racism, Ethnic and Racial Studies, vol.19, no.4,(1996) pp. 864-883

Booth, Charles, Life and Labour of the People in London, Third Series: Religious Influences, Vol. II London North of the Thames: The Inner Ring. London: MacMillan and Co. 1902

Booth, Charles, Life and Labour of the People in London, Third Series: Religious Influences, Vol. IV, Inner South London. London: MacMillan and Co., 1902

Booth, Charles Life and Labour of the People in London, First Series: Poverty, Vol. I, East, Central and South London. London, Macmillan and Co., 1904

Brah, Avtar, Cartographies of Diaspora: Contesting Identities. London: Routledge, 1996

Bressey, Caroline and Dwyer, Clair (eds.) New Geographies of Race and Racism. London: Routledge, 2016 Brooke, Stephen, 'Space, Emotions and the Everyday: The Affective Ecology of 1980s London' $20^{\text {th }}$ Century British History, Vol. 28, Issue 1, (2017), pp.110-142

Brown, Colin, Black and White Britain, The Third PSI Survey. London: Heinemann, 1984

Bunyan, Tony, 'The police against the people' Race and Class, (October 1981) (23) 2-3

Burgess, J.A and Gold, J.R (eds.) Geography, The Media and Popular Culture. London: Croom Helm, 1985 Burgess, Jacquelin, 'News from Nowhere: The press, the riots and the myth of the inner city' in Burgess, Jacquelin and Gold, John R. (eds.) Geography, The Media and Popular Culture. London: Croom Helm, 1985 Cashmore, Ernest and Troyna, Barry 'Black youth in crisis' in Cashmore and Troyna, (eds.) Black Youth in Crisis. London: Allen and Unwin, 1982

Conteh-Morgan, Earl, Collective Political Violence: An Introduction to the Theories and Cases of Violent Conflicts, New York: Routledge, 2004

Davis, Jennifer, 'From 'Rookeries' to 'Communities': Race, Poverty and Policing in London, 1850-1985'

History Workshop, No. 27 (Spring 1989) pp.66-85

Eades, John, Placing London: From Imperial Capital to Global City. Oxford: Berghahn Books, 2000

Englander, David (ed.), A Documentary History of Jewish Immigrants in Britain 1840-1920, London: Leicester University Press, 1994 
Englander, David, 'Booths Jews: The presentation of Jews and Judaism in Life and Labour of the People in London' in Englander, David and O’Day, Rosemary (eds.), Retrieved Riches: Social Investigation in Britain, 1840-1914. Aldershot: Scolar Press, 1995

Evans-Gordon, William, The Alien Immigrant. London: W. Heinemann, 1903

Feldman, David, 'The Importance of being English: Jewish immigration and the Decay of Liberal England' in Feldman, David and Stedman Jones, Gareth (eds.), Metropolis London: Histories and Representations since 1800. Oxford: Routledge, 1989

Feldman, David, Englishmen and Jews: Societal Relations and Political Culture. New Haven: Yale University Press, 1994

Feldman, David, 'Jews and the British Empire, c.1900’ History Workshop Journal, Vol. 63, Issue 1 (2007) pp.70-89

Fishman, William J. East End Jewish Radicals, 1875-1914. London: Gerald Duckworth and Co., 1975

Fishman, William J. East End 1888. Nottingham: Five Leaves Publications, 2005

Gainer, Bernard, The Alien Invasion: The Origins of the Aliens Act of 1905. London: Heinemann Educational, 1972

Gidley, Ben 'Citizenship and Belonging: East London Jewish Radicals 1903-1918', (PhD, Goldsmiths College, London, UK, 2003)

Gibson-Brydon, Thomas R.C (edited by Hillary Knell and Brian Lewis), The Moral Mapping of Victorian and Edwardian London: Charles Booth, Christian Charity and the Poor-But-Respectable. Montreal: McGill-

Queen's University Press, 2016

Gilroy, Paul 'You Can't Fool the Youths', in Race and Class, 2-3 (October 1981)

Gilroy, Paul, There Ain't No Black in the Union Jack. London: Routledge, 1987, republished 1992

Gilroy, Paul, 'Police and Thieves' in Centre for Contemporary Cultural Studies, The Empire Strikes Back.

London: Routledge, 1992

Glover, David, Literature, Immigration, and Diaspora in Fin-de-Siècle England: A Cultural History of the 1905 Aliens Act. Cambridge: Cambridge University Press, 2012

Glynn, Sarah 'East End immigrants and the battle for housing: a comparative study of political mobilisation in the Jewish and Bengali communities' Journal of Historical Geography, 31 (2005), pp. 528-545

Gordon, Paul and Rosenberg, David, Daily Racism: The Press and Black People in Britain. London: Runnymede Trust, 1989

Hall, Stuart, Critcher, Chas, Jefferson Tony, Clarke, John and Roberts, Brian, Policing the Crisis: Mugging, The State and Law and Order. London: Macmillan, 1978

Hilliard, Christopher, 'Words that Disturb the State: Hate Speech and the Lessons of Fascism in Britain, 1930s to 1960s, The Journal of Modern History 88:4 (December 2016) pp.764-796

Holmes, Colin, Anti-Semitism in British Society, 1876-1939. London: Edward Arnold, 1979

Horowitz, Donald L., The Deadly Ethnic Riot. Berkley: University of California, 2001

Howe, Darcus, From Bobby to Babylon: Blacks and the British Police. London: Race Today Publications, 1988. Inwood, Stephen, A History of London. London: Papermac, 2000

Institute of Race Relations, Race, Class and the State: The Black Experience in Britain (London: Institute of Race Relations, 1976. 
Jacobs, Joe, Out of the Ghetto: My Youth in the East End, Communism and Fascism 1913-1939 (London: Janet Simon, 1978

Jackson, Peter, 'Street Life: The Politics of Carnival' Environment and Planning D: Society and Space, Vol. 6, No.2, (1988) pp. 213-227

Jackson, Peter 'Afterword: New Geographies of Race and Racism' in Bressey, Caroline and Dwyer, Clair (eds.) New Geographies of Race and Racism. London: Routledge, 2016

Julius, Anthony Trials of the Diaspora: A History of Anti-Semitism in England. Oxford: Oxford University Press, 2010

Keith, Michael 'Something Happened: The Problems of Explaining the 1980 and 1981 Riots in British Cities', in Jackson, Peter (ed.) Race and Racism: Essays in Social Geography, London: Allen and Urwin, 1987

Keith, Michael, Race, Riots and Policing: Lore and Disorder in a Multi-Racial Society, London: UCL Press, 1993

Kershen, Anne, Uniting the Tailors: Trade Unionism Among the Tailors of London and Leeds, 1870-1939. Ilford: Cass, 1995

Kershen, Anne 'The migrant at home in Spitalfields: Memory, myth and reality' in Burrell, Kathy and Panayi, Panikos (eds.) Histories and Memories: Migrants and their History in Britain. London: Tauris Academic Studies, 2006

King, Anthony D., Global Cities: Post-Imperialism and the Internationalization of London. London: Routledge, 1990

Kushner, Tony 'The end of the 'Anglo-Jewish' progress show', in Kushner, Tony, (ed.) The Jewish Heritage in British History. London: Frank Cass, 1992

Kushner, Tony, "'Long May its Memory Live!”: Writing and Rewriting “the Battle of Cable Street” in Kushner, Tony and Valman, Nadia, (eds.) Remembering Cable Street: Fascism and Anti-Fascism in British Society.

London: Vallentine Mitchell, 2000.

Lawrence, Errol, 'Just plain common sense: the 'roots' of racism' in Centre for Contemporary Cultural Studies, The Empire Strikes Back. London: Routledge, 1992

Lebzelter, Gisela C., Political Anti-Semitism in England, 1918-1939. London: MacMillan, 1978

May, Jon 'Globalization and the Politics of Place: Place and Identity in an Inner London Neighbourhood' Transactions of the Institute of British Geographers, Vol. 21, No.1, (1996), pp. 194-215

McGhee, Derek Intolerant Britain? Hate, Citizenship and Difference. Maidenhead: Open University Press, 2005 McGuinness, Mark 'Geographies with a difference? Citizenship and difference in postcolonial urban spaces', in Blunt, Alison and McEwan, Cheryl (eds.), Postcolonial Geographies, London: Continuum, 2002

Moore, Robert, Racism and Black Resistance. London: Pluto Press, 1975.

Nanton, Philip 'The Caribbean Diaspora in the Promised Land' in Kershen, Anne, London, The Promised Land: The Migrant Experience in a Capital City. Aldershot: Ashgate Publishing Limited, 1997

Patterson, Shelia, Dark Strangers: A Study of West Indians in London. Harmondsworth: Penguin Books 1963 (republished 1965)

Peach, Ceri, West Indian Migration to Britain: A Social Geography. London: Oxford University Press, 1968.

Peach, Ceri (ed.), Urban Social Segregations. London: Longman, 1975 
Perry, Kennetta Hammond, London is the Place for Me: Black Britons, Citizenship and the Politics of Race. Oxford: Oxford University Press, 2015.

Petrow, Stefan, Policing Morals: The Metropolitan Police and the Home Office, 1870-1914. Oxford: Clarendon Press, 1994

Pilkington, Racial Disadvantage and Ethnic Diversity in Britain. Basingstoke: Palgrave Macmillan, 2003

Ramdin, Ron, The Making of the Black Working Class in Britain. Aldershot: Wildwood House, 1987

Rocker, Rudolph, The London Years. Nottingham: Five Leaves Publications, 2005

Rowe, Michael, The Racialisation of Disorder in Twentieth Century Britain. Aldershot: Ashgate, 1998

Roberts, Brian, 'The debate on Sus', in Cashmore, Ernest and Troyna, Barry (eds.) Black Youth in Crisis.

London: Allen and Unwin, 1982

Salway, John, Reading the Riot Acts: Behind the Headlines and the Frontlines. London: Lambeth Archives, 2005

Scarman, L.G, The Scarman Report: The Brixton Disorders, 10-12 April 1981. Harmondsworth: Penguin, 1982) Sivanandan, Anbalavaner. Race, Class and the State: The Black Experience in Britain, London: Institute of Race Relations, 1976

Sivanandan, Ambalavaner 'From resistance to rebellion: Asian and Afro-Caribbean struggles in Britain' Race and Class, 23 (2-3) (October 1981) pp.111-152

Solomos, John, Black Youth, Racism and the State: The Politics of Ideology and Policy. Cambridge: Cambridge University Press, 1988

Solomos, John, Race and Racism in Britain. Basingstoke: MacMillan Press Ltd., 1993

Schwarz, Bill, 'Claudia Jones and the West Indian Gazette: Reflections on the Emergence of Post-Colonial Britain’ in Twentieth Century British History, 14:3 (2003) pp.264-285.

Tananbaum, Susan L. '”Morally Depraved and Abnormally Criminal”: Jews and crime in London and New York, 1880-1940' in Berkowitz, Michael, Tananbaum, Susan L. and Bloom, Sam W. (eds.) Forging Modern Jewish Identities. London: Vallentine Mitchell, 2003

Taylor, David, 'Cass, Coverdale and Consent: The Metropolitan Police and Working-Class Women in LateVictorian London' in Cultural and Social History, 12:1,(2015) pp. 113-136

Tilly, Charles, The Politics of Collective Violence. Cambridge: Cambridge University Press, 2003

Thurmond Smith, Philip Political Policing, Public Order, and the London Metropolitan Police. Westport,

Connecticut: Greenwood Press, 1985

Van Onselen, Charles, 'Jewish police informers in the Atlantic world' The Historical Journal, vol. 50, no.1,

(March 2007), pp.119-144

Walkowitz, Judith, City of Dreadful Delight. London: Virago Press, 1992.

Watt, Paul, 'Respectability, Roughness and "Race”: Neighbourhood Place Images and the Making of WorkingClass Social Distinctions in London', International Journal of Urban and Regional Research, 30 (2006), 77597.

White, Jerry Rothschild Buildings: Life in an East End Tenement Block 1887-1920. London: Routledge and Kegan Paul, 1980 
Wild, Rosie, 'Black was the colour of our fight' in Kelley, Robin D.G and Tuck, Stephen, (eds.) The Other Special Relationship: Race, Rights and Riots in Britain and The United States. New York: Palgrave Macmillan, 2015 